\title{
Ethical Questions on the Governance of the Internet
}

\author{
Jacques BERLEUR \\ IFIP-TC9 and SIG9.2.2 Chair \\ University of Namur (Belgium) \\ jberleur@info.fundp.ac.be,http://www.info.fundp.ac.be/ jbl
}

Key words: Code of ethics, deontology, governance of the Internet, self-regulation

\section{INTRODUCTION}

The writings that initially launched the debate on the ethics of computing date back to 1985. 'Computers and Ethics' was the title of a special edition of the journal Metaphilosophy, published by Terrell Ward Bynum, ${ }^{1}$ in which James Moor defined 'Computer ethics', a term which was reused in Deborah G. Johnson's book, which would become a classic in its class. ${ }^{2}$ And here we are today invited to think about 'Cyberethics'.

We should not forget, however, that Joseph Weizenbaum's 1976 Computer Power and Human Reason explicitly touched upon the question of ethics, specifically in chapter 10, 'Against the imperialism of instrumental reason', in which he indicated the types of research that he would not undertake, except after careful consideration and within defined limits. ${ }^{4}$ It should also be remembered that from 1979 to 1982 the Council of Europe, under the direction of Herbert Maisl, drew up a number of reports on the deontology of computing, but which were not followed up, other than in the form of the normal Council recommendations of a more legal nature. ${ }^{5}$

The available literature in the English language has become abundant and, all too often, everything and anything becomes an occasion to reorder, under the heading 'Computer Ethics', subjects which would otherwise fall into the category of 'Computers and Society': privacy, the responsibility and reliability of software, intellectual property rights, computer crime, security, and so on. This hesitation is felt in the attempts at classification, such as that of Herman Tavani for example. ${ }^{6}$ We are not fond of the term 'Computer Ethics' and prefer 'Ethics of Computing', one that better allows us to 
comprehend the choices that individuals, companies, and society are able to make.

Few works in the French language are to be found under the category 'Ethics of Computing' or under similar categories, but numerous subjects are reused elsewhere in the doubtless more disciplinary works. This is certainly the case for issues in which the law intervenes more explicitly.

We might like to focus our subject matter and follow the development of works that have been carried out within the International Federation for Information Processing (IFIP). ${ }^{7}$ They will successfully illustrate, we believe, the trends that are found again in the mainly Anglo-Saxon works, whose global influence is growing.

The IFIP has mainly worked in three domains of the ethics of computing: the codes of deontology of its member Societies, the position of ethics in the governance of the Internet and more recent questions about self-regulation.

\section{ON THE CODES OF ETHICS OR OF CONDUCT FOR IT PROFESSIONALS}

From 1988 to 1992, the IFIP as an international association examined the possibility of adopting an international code of ethics that would have bound all of its members. However, apart from some members, who were individually recognised for their service to the federation, membership of the IFIP is only awarded to national Societies who are composed mostly of IT professionals. This situation in a way renders obsolete those arrangements that bind just the associations and not the individuals. Furthermore, certain unwillingness was exhibited by numerous member Societies to a way of advancing which would cause the cultural, social and legal differences to be less apparent and that would impose an approach that in effect was more characteristic of an already dominant culture. ${ }^{8}$

Starting almost from scratch, a Task Group carried out an analysis of all the existing codes within the IFIP and proposed recommendations, which were adopted at its General Assembly meeting in $1996 .{ }^{9}$

The objects of this study were the roughly thirty professional codes enacted by 20 Societies (of the fifty or so having a statute of full member, affiliate, or corresponding).

No title seems meaningful: both codes of ethics or of conduct are spoken of, as are guidelines, standards and so on. The obligations most often link individual members, but can sometimes concern the Societies themselves. It is interesting to note that the obligations refer not only to customers, but also to the society as a whole, or to 'users', thus overreaching the strict design of codes of professional deontology. 
A pattern emerges from the analysis, which concerns the contents on which the duties are based. Five main fields of obligation are thus covered:

- a general attitude of respect, including respect for the interests or rights of the people involved (15/30), respect for the prestige of the profession (11), respect for the interests or rights of the public (10), and respect for the welfare, health of the public and for the quality of life (10);

- personal (/institutional) qualities such as professional conscientiousness, honesty and positive attitude, competence and efficiency: conscientiousness and honesty are encountered under the expressions such as acceptance of responsibility (19/30), integrity (26), respect for contractual obligations (14), conscientious work (11), professionalism (7), the credit given for work done by others (6); competence and efficiency are covered by terms such as professional development and training (19), the limitation of work to one's field of competence (18), general competence (13), efficiency and quality of work (12), etc.;

- the promotion of the private character of information and the integrity of data: confidentiality (22/31), privacy in general (14), respect of property rights (12), no computer crime, no information piracy or misuse (7), etc.

- the production and the flow of information: flow of information to concerned parties and to individuals (23/31), public information (16), and so on; and finally

- an attitude vis-à-vis regulations: respect for the code (13/30), laws (13), professional standards (12).

Examination was also made of the capacities of enforcement, the procedures relative to complaints and penalties. This comparison turned out less straightforward, since membership structures often affect the efficiency of penalties or sanctions in particular.

We have said: these codes are the distinctive feature of a very AngloSaxon tradition, that has been anchored in countries that have had regular contact with the United Kingdom, such as Australia, Canada, the USA, India, Zimbabwe, New Zealand, and so on. Of the twenty or so Societies counted, only two escape this sphere of influence, Italy and Germany.

Furthermore, to avoid falling back into 'monoculture', it has appeared wise to recommend that these elements of analysis be examined by other national Societies in the 'Spaces for discussion', which evaluate its relevance. The Task Group has suggested developing a 'procedural ethic', according to the more theoretical views of Jürgen Habermas, ${ }^{10}$ as well as one in which beliefs and convictions may be exchanged, from which an order of principles may arise that can be developed in the various situations. ${ }^{11}$ 
The method seemed all the more important because an in-depth work should be embarked upon in the domains most directly linked to computing. Of the five domains mentioned above, two effectively deal with questions more directly linked to this discipline. The IFIP has suggested paying particular attention to questions, such as those, which are regulated today by the Council of Europe's recent convention on cybercrime: illegal access to, or illegal interception of data, data interference, system interference, misuse of devices, computer-related forgery, computer-related fraud, offences relating to child pornography, offences relating to infringements of copyright and related rights, attempt and aiding or abetting. ${ }^{12}$ The IFIP had also underlined that the development of the Internet should focus more closely on the diversity of nations and that questions could only be addressed on the basis of respect for differences and therefore that it was urgent to put in place spaces for discussion, where problems could be examined according to different cultural, social and legal situations. In whatever form it takes, the important issue was that the ethical question remains in place in the different debates that surround the development of information and communication technologies.

\section{ETHICS AND THE GOVERNANCE OF THE INTERNET}

The questions linked to the governance of the Internet came to light, or in any case, became more lively in October 1998, at the moment of transfer of authority for the attribution of IP addresses and domain names from the IANA (Internet Assigned Numbers Authority), under contract with the US government, to the ICANN (Internet Corporation for Assigned Names and Numbers), a private non-profit association, which represents the interests of the business world, the technical world, the academic world and the wider community of Internet users.

However, by launching its campaign 'One Planet, One Net' in December 1997, an association of activists called the Computer Professionals for Social Responsibility (CSPR) made known that the debate on governance was not restricted to technical questions of the IANA and the ICANN, but also covered questions of standardisation, content development and control, as well as access to the Internet. ${ }^{13}$

Defenders of regulation, of non-regulation, of an unfettered and unregulated Internet, ${ }^{14}$ of a co-regulated Internet have provoked a debate that is far from over today.

A certain number of initiatives in relation to Internet codes had preceded this process of awareness. We reflect on the 10 commandments of the Computer Ethics Institute, Washington DC (1992), on the 12 commandments of the Internet issued by the Internet Society of New 
Zealand (1997), on the Wartburg Charter developed in the context of the closure of German sites of Compuserve (1997) in connection with certain illicit content found on its servers, on the French Internet Charter (1997), proposed immediately after the work of the A. Beaussant Commission, not forgetting the rules of Netiquette ${ }^{15}$ or the numerous codes developed specifically by associations of service providers, etc.

All these documents were in the charge of groups which were larger than the professional IT societies and, one way or the other, were attempting to show certain problems linked to the Internet, either to offer some first solution principles, or to suggest procedures, or simply with the aim of 'legally' protecting the firms or organisations which were involved in the Internet. Thus, the British 'Internet Service Provider's Code' (ISPA-UK, 1996, Rev. 1999), for example, or the one from the same association in Belgium (ISPA-Be, 1998), or the French Internet Charter, (although it was never adopted), were quite representative of the questions being studied by the service providers associations. The subjects and domains towards which the 'Internet actors' made a commitment to respect certain rules and usages, dealt with manifestly illicit content and actions (mainly paedophilia, incitement to racial hatred, denial of crimes against humanity, the call to murder, mediating for prostitution, drug trafficking, attacks against national security), prejudicial, harmful and sensitive content (pornography and violence) $^{16}$, fundamental rights and freedoms (freedom of expression, right to information, safety, privacy, property rights, and so on), protections of intellectual property rights, the protection of consumers in electronic commerce.

But where was the ethical dimension in all that? Certain documents appeared normative, without any doubt, but nevertheless remained very vague in their stipulations. Others went into detail, but quickly turned out to be a way for service providers, for example, to protect themselves in relation to voluntary and involuntary abuses by their clients.

The IFIP Special Interest Group on Ethics of Computing documents (IFIP-SIG9.2.2) has drawn up a certain classification and a rearrangement of the questions in these. ${ }^{17}$ There are, we conclude, what one might call a pragmatic agenda for which 'electronic commerce' will undoubtedly be one of the motors. We find again questions related to risk, to security measures, to reliability, to legal responsibility, to intellectual property rights, to all that is to be found under the category of 'computer crime', to the examination of the protection of competition, to questions of privacy and of confidentiality, to encryption and to questions linked with the key escrow, to the protection of consumers (among others vis-à-vis the power of monopolies), etc.

Some of these questions were already on the agenda of governments and international and public authorities. One could doubtless add diverse lesspublicised questions to the list: at a cultural level - the study of all 
technological dreams, utopias, metaphors, and their power of selflegitimisation and, more fundamentally, all the questions linked to education and training; at the socio-economic level - the impact on the world of organisations and, finally, the re-examination of the roles of governments and the questions raised by the concepts of 'co-regulation' or 'multiregulation', as discussed during the 1999 Summit of the Regulators, to which we shall return later. ${ }^{18}$

IFIP-SIG9.2.2 therefore proposed to concentrate the ethical debate on questions, some of which featured, perhaps, on the 'pragmatic agendas', but on the subjects where ethical content was even more explicit: equity in the right of access and specifically 'universal service', questions linked to the respect of the dignity of the person - protection of minors and human dignity, illegal and harmful content, paedophilia, racial hatred, denial of crimes against humanity, incitement to murder, to drug trafficking, violence and so on; questions of social justice and exclusion - the 'digital divide' not only in North-South relations, but also in the redistribution of labour. Respect for the interests and the rights of the individual, free speech and the examination of questions of censorship, quality of life, the right to information, personal qualities (honesty, competence), the refusal of the abuse of power. Respect for cultural differences, the anchoring of the virtual in the real, upholding the freedom of choice in relation to electronic services, etc. ${ }^{19}$

In conclusion, IFIP-SIG9.2.2 called for a clarification of questions under debate, in attempting to specify their cultural, economic, legal, social or ethical character to better measure the interests of the actors present. It noted the return of ethics in the field of daily practice (the 'lifeworld' of Habermas) and advocated, like in 1996, the development of spaces for discussion where the whole of these questions could be debated by all the actors involved in governance. It did not exclude the argument forwarded by certain people of an 'instrumentalisation of ethics' aimed at employing the probable legitimisation of moral measures to clean up the Internet, and so lead the charge against opponents of regulation itself, by imposing a system of self-regulation that would protect private interests. Who knows? It matters, we repeat, that the ethical dimension is present in debates about governance, since it is about the domination of technological development, about 'control', about regulation of a technological system integrated into our social practices.

\section{ETHICS AND SELF-REGULATION}

Since 1999 governance seems to press the question of self-regulation more forcefully. Why 1999? The debate clearly pre-dates this. Codes of 
deontology, which have already been mentioned in the first section, already represent a sort of self-regulation, as do too the widely distributed codes of 'Business Ethics'. In March 1998 the Business and Industry Advisory Committee (BIAC) and the OECD jointly organised a Forum on Internet Content Self-regulation. ${ }^{20}$ We note however that the list of 'relevant sites and documents' was still not very rich. We are specifying 1999, because events appear to stand out: the Summit of the Regulators that we have already mentioned, the work of the Bertelsmann Foundation on the selfregulation of Internet content and the 'recommendations' of the Global Business Dialogue on Electronic Commerce (GBDe), created in January 1999, whose first assembly was held in Paris on 13 September of that same year,.

Starting again its research of self-regulation in a more systematic way, IFIP-SIG9.2.2 established a classified inventory of about forty texts adding to the thirty or so professional codes previously listed. Their analysis had been established following an analytic framework identical to that normally used in the analysis of legal texts: we examined, successively, ratione personae, the authors and individuals concerned or affected, then ratione $l o c i$, the geographical areas in which the agreements were applicable, then ratione materiae, the subjects and domains mentioned, and finally the application measures or enforcement and the sanctions and penalties. ${ }^{21}$

This is not the place to expand upon the results of the analysis of those documents. We have done so elsewhere. ${ }^{22}$ We will however, go over some essential elements related to the governance of the Internet. What immediately comes to mind is that we have nowadays given up on selfregulation 'in general' to expand it in more and more specific domains of virtual communities, service providers (as already mentioned), the other service providers (less localised, such as Excite, GeoCites \& Yahoo, Global One, and so on), certain services and governmental actors, industry in general, and finally a set of private sectors, - among these that of health, editing, electronic commerce, software publishers, telemarketing, and so on. However, from the most general to the most specific, the form of norms seems to be changing from norms of more or less deontological nature when it concerns the Internet in general, to increasingly precise clauses, but of an essentially contractual type when we tackle the most specific domains and, above all, the specific sectors. Thus, in examining, for example, the eHealth Code of Ethics by the Internet Health Care Coalition, we will not be surprised to note that when buying medical 'products and services' one engages in 'responsible business relationships' and that one is guaranteed 'best business practices' ${ }^{23}$ Medical treatment is dealt with in a very similar way to all 'business'. We are not really surprised when we learn that 52 million Americans look up medical and health information on the web and that the paper which gives that information in fact comes from the 
Department of Trade $!^{24}$ The rules of the advertising and marketing organisations on the Internet point out, from their side, that obligations exist concerning: the declaration of identity, the information to be supplied to consumers and its quality, the non-sending of unsolicited commercial messages, etc. ${ }^{25}$ In the publishing sector, we are told how many paragraphs we may quote - without prior consent - without being prosecuted for plagiarism, as well as conditions for 'electronic reproduction' or archiving, etc. ${ }^{26}$

Where are ethics in all that, without reducing the rules to good conduct, very often unchecked, if not 'uncheckable', and, in any case, devoid of any complaints procedure or penalties?

Self-regulation, regulation, co-regulation? Such were the key words of the Regulators World Summit of 1999 that we already mentioned earlier, a gathering of more than 60 regulating authorities from five continents. ${ }^{27}$ Does that mean that everyone sung in chorus? Far from it. Certainly, for some (Canada, for example), self-regulation seemed to be accepted, it should be accompanied by parental guidance. For others (Lebanon, Burkina-Faso, Italy, for example), at the extreme end, regulation should be set at many levels, where fitting: at the international level first, general rules; at the national level, following and in accordance with the first, their specification. The proponents of co-regulation (Australia) proposed the development of codes of conduct in partnership and in accordance with the Australian Broadcasting Authority. M. Vivant underlined in his summary of the debates, that without a will to make everyone agree, it seems quite evident that the Internet will experience 'multi-regulation' or a 'plural regulation' while noting that in view of the present inequalities - notably in access to the Internet - "between the strong and the weak, it is the law that liberates and freedom that oppresses." (Lacordaire) As for co-regulation, the concept in itself demands clarification, because if, for some, it means that selfregulation is not envisaged except under the charge of public authority, for others it implies the application of a strict principle of subsidiarity. M. Vivant suggested considering "the institution of dialogue and consultation structures between public and private Internet actors." It is in this sense, very certainly, that the Forum of Internet Rights was set up in France in $2001^{28}$

On the subject of self-regulation, it is certain that the electronic commerce sector is getting all the attention today, if not from all partners and protagonists, at least as much as from those promoting it. To give an example, we might reflect on the Dutch initiative 'Electronic Commerce in Nederland' (ECP.NL) and on its 'Model Code of Conduct', whose simplicity has not greatly changed as one advances through successive versions: reliability, transparency, privacy, confidentiality remaining the only chapter headings. In spite of the many comments concerning the 
necessity of anticipating rules on enforcement, as well as a complaints and penalties process, nothing is visible in the final version, except, as was already indicated in previous versions, that it would be a good idea to plan them. ${ }^{29}$

Another motor of self-regulation in electronic commerce is certainly the Global Business Dialogue on Electronic Commerce (GBDe) whose president of the French Forum on Internet Rights, Mrs Is. Falque-Pierrotin, wrote at the end of 1999 that it was about "a caricature of this new Church that wants to limit state intervention as much as possible in the name of pragmatism and economic realism." ${ }^{30}$ The 'caricature' is on the up! GBDe is an initiative of CEOs of big businesses such as AOL Time Warner, Fujitsu, Vivendi Universal, Accenture, Toshiba, Telekom Malaysia, Korea Telecom Freetel, Cisneros Group of Companies, Seagram, Eastman Kodak, Walt Disney, Hewlett Packard, IBM, MCI Worldcom, Alcatel, ABN AMRO Bank, DaimlerChrysler. With their 'sherpas', the CEOs go from summit to summit, the 'Davos' of eCommerce as they say. In Paris in 1999, 8 topics were on the agenda: authentication and security, consumer confidence, commercial communication and content, infrastructure and market access, intellectual property rights, legal jurisdictions and responsibilities, the protection of personal data, and taxes and tariffs. At the summit in Miami in 2000 , the themes were much the same, but we see alternative methods of dispute resolution, digital bridges (as opposed to digital divides); cybercrime, commercial trustmarks. The Tokyo summit in 2001 brought some new modifications into the scope of the conference, thus the list became: consumer confidence (personal data privacy protection, alternative dispute resolution, trustmarks), convergence, cultural diversity, cybersecurity, digital bridges, eGovernment, intellectual property rights, Internet payments, taxation, and trade/WTO. ${ }^{31}$ The Brussels (2002) and Tokyo (2003) recommendations have added new items such as the Brodband, the Spectrum management policy, the unsolicited electronic communication (Spam), and the Radio Frequency Identification (RFID).

The reports exhibited during these summits still have not taken the form of self-regulation documents, but are full of recommendations to companies, as well as to public authorities. Two examples: in the recommendations on eGovernment (Tokyo 2001), the authors noted (within a dozen lines) that the success of IT investments will heavily depend on the digitalisation of government administrative functions. They then recommended certain specifications for eGovernment, from the point of view of the private sector, that would contribute to its effective achievement, then concluded: "the new role assignment will be a model for a new social system" (sic!) ... able to make the aforementioned investments profitable (Nda). In another field, that of 'Cyberethics', a Statement of Principles on Cyberethics in two pages, does not talk much about subjects other than prevention relating to 
"unethical material, such as pornography involving children, anti-Semitic, racist or xenophobic content" and the promotion of "free speech and expression as well as artistic and journalistic freedom." Nothing in this declaration concerning the other domains in which the GBDe operates intensively, it is as if no ethical questions were raised there.

Finally, we would like to briefly evoke the hard work carried out under the direction of the Bertelsmann Foundation, and in particular its political media division, on 'self-regulation of Internet content' ${ }^{32}$ It is useful to know that talking about 'content' regarding the Internet is the same as talking with prudery about what was brought up in the European Commission's Green Paper on the protection of minors and human dignity, the Communication on Illegal and Harmful Content on the Internet, and the Action Plan on Promoting Safe Use on the Internet, the so-called 'Internet Action Plan'. ${ }^{33}$ The Foundation's project, carried out from $1^{\text {st }}$ February 1999 to the end of March 2001, comprises several parts: support for hotlines, codes of conduct, the development of filters, education in schools, and so on. Several seminars punctuated the project's steps, aimed at developing alternative regulatory structures and at increasing the awareness of the new roles played by service providers and users; to guarantee the effective protection of minors, while not hindering the free flow of information, and to promote filer technologies. One 'Model Code' was put to discussion. ${ }^{34}$ It concerned propositions essentially aimed at content and service providers and which dealt with illegal and illicit content, with the position to adopt when faced with unwanted messages, with the protection of data and with privacy and so on. In fact, we are faced with a library of existing codes that have the advantage of representing widespread ideas. We also appreciate the offer of public consultation and the evaluation framework that accompanied this 'Model Code'. We have been recently informed by the Bertelsmann Foundation that there was no follow up to the 'Model Code' proposal. We mention again that the Bertelsmann Foundation is one of the partners of the Internet Content Rating Association (ICRA) which today is trying to promote labelling standards within the framework of, notably, the Internet Action Plan. ${ }^{35}$ Here again we find some large firms, AOL Inc., Bell Canada, British Telecom, Cable and Wireless, IA Japan, IBM, Microsoft, Yahoo, besides, of course, organisations whose prime function is to protect children from the dangers of the Internet: the Internet Watch Foundation, the Parents Advisory Group for the Internet, Kids Domains Inc, amongst others.

Would it not be correct to question the reasons for the presence of all these firms in the nerve centres of Internet self-regulation, in particular in a field as sensitive as the protection of children? Curiously, public authorities appear absent if not sidelined from these places, where the common good should prevail and where fundamental ethical debate begins. Would it not also be right to question the power of organisations whose convergence is 
precisely one of the major economic interests? Where is the leeway for the public in this game?

IFIP-SIG9.2.2 concentrates today on defining what it believes should be the minimum standards to which the self-regulation codes should conform, specifically from the ethical point of view. Similar works have been undertaken in relation to eCommerce, using the framework of the International Chamber of Commerce, for example ${ }^{36}$. We also reflect on the eConfidence Forum programme of the European Commission and on the principles that are being discussed regarding codes of conduct for eCommerce. ${ }^{37}$ The Bertelsmann Foundation's 'Model Code' proposition doubtless comes down to the same preoccupation in the field of the protection of content.

\section{CONCLUSION}

To be read and known, a code should, we say, be brief. The other side of the coin is that it will be terminally vague, or, in any case, will not go into too many details. Would it be enough to guarantee a minimum of regulation? How can a code deal with questions like privacy in a few lines, whereas the European directive on the subject $95 / 46 / \mathrm{CE}$ expands on 34 articles, spread over 20 pages of the Official Journal of the European Communities? Reading these codes is sometimes perplexing and we have the right to ask if laisser-faire is an adequate solution. What is their place in the legal pluralism? Are they a complement or a substitute to the law or are they the anticipation of it?

Our object was not to ask ourselves questions about self-regulation as such, but rather to consider the ethical questions surrounding the governance of the Internet. It is the question of governance itself that has led us to question self-regulation. And it is from within this concern that our questioning has sprung.

The recent tendency to multiply the instruments of self-regulation compels us to ask the question as to whether, in the name of ethical requirements, there are not contents that should escape self-regulation. ${ }^{38}$ Should we leave it up to certain private interests, even if they are enlightened, to define the norms in domains that concern relationships not only to economic, but also cultural, social and political life? We have given ourselves a criterion that, without solving everything, appears to us to be a direction for reflection, one that is linked to the Kantian type of deontology: as soon as the interests of the majority are put at risk and the individuals concerned by that risk are being made more vulnerable and fragile, an authority should intervene that keeps open the 'horizon of universalism (or universalisation)' specific to the ethical dimension. ${ }^{39}$ It is clear that this 
criterion, and in particular the 'horizon of universalism (or universalisation)' leads to a concentration of the primordial questions to be put to discussion: equality of rights of access, the fights against social exclusion, the protection of minors and of human dignity, etc.

It seems to us, however, that ethical questions do not only deal with content targeted by self-regulation, but also with the procedures through which the democratic game risks being played, out-manoeuvred or threatened. Participation in the creation of instruments of self-regulation appears essential. Is there no space to go further and to define a legal framework - according to normal democratic criteria - that allows the development of instruments of self-regulation that genuinely instil trust in people, because they will have been involved in one way or another, most specifically through systems of representation?

From the perspective of the procedural ethic that we have drawn up, ethical and democratic questions tend to meet. It would seem difficult to plan for self-regulation, such as would not be framed by law, without risking an ethical deficit.

A number of arguments put forward are often nothing but false explanations. One assumes that everything is worldwide in this global village and that the law is territorial. But one forgets to see that codes - in any case everything that we have examined - do not solve this question, for they are also all 'local'. We say that the problems are new and that the law is ill-prepared. Are we thus implying that judges are more ignorant than socalled experts? We might also insist on the subjects' evolutionary rhythm. It cannot be denied. But is it a reason for adopting tools, often hastily written, whose only effect at the end of the day is to inexpensively satisfy certain insufficiently expressed demands? $?^{40}$

The governance of the Internet should more circumspectly examine the questions that it has itself raised and which commit one more than the oftenrepeated shallow interests. It seems urgent to us to deepen the reflection, which we believe has been accumulated by the various codes of good conduct, but which will not be effective unless these take the ethical dimension into account. According to the Kantian categorical imperative that we referred to earlier, only that which is for the good of everybody is 'ethical'.

It is fine and good that some measures have been taken for protective reasons. But it would be doubtless misguided to have stuck at that and had to have defended some of them with an apparent air of morality. Promoting the ethics of governance means at least two things: increasing the participation of everyone in the procedures of drawing up self-regulatory documents and developing content of the sort that also protects interests other than the strictly economic. 
May we be forgiven our insistence, our repetitions and our final revision, made without much care for literary norms? In our opinion we must, without delay:

- Pay special and particular attention to questions such as equality of rights of access and especially 'universal service', questions linked to respect for the dignity of the individual - protection of minors and human dignity, struggle against illegal and harmful content, paedophilia, racial hatred, the denial of crimes against humanity, incitement to murder, drug trafficking, violence, and so on; questions of social justice and exclusion, the 'digital divide', - not just North-South, but also in the redistribution of labour; the respect for the interests and rights of individuals, freedom of speech and the examination of questions of censorship, quality of life, freedom of information, personal qualities (honesty, competence), the refusal of the abuse of power, respect for cultural differences, the anchoring of the virtual in the real, the upholding of freedom of choice relating to electronic services, etc;

- Have everyone concerned participating, especially in the drawing up of codes of self-regulation;

- Ask ourselves if the current self-regulation documents are not, primarily, documents about self-protection;

- Agree to stop putting arguments which we know are pertinently false: the necessity to overcome legal jurisdictions, the urgency of filling legal voids, etc;

- Watch that no-one wrongfully grants themselves roles that belong to society as a whole;

- Enforce codes and let nothing into a statute that risks making it a mere pious wish. Set up penalties and procedures for complaints;

- Articulate self-regulation in law;

- Etc.

1 Moor, James H., What is computer ethics?, in: Bynum, W. T., Ed., Computers and Ethics, Metaphilosophy, Volume 16, No. 4, October 1985, Basil Blackwell, Oxford and New York, pp. 263-353.

2 Johnson, D. G., Computer Ethics, Englewood Cliffs, N. J.: Prentice-Hall, Inc., $1985,{ }^{2} 1994,{ }^{3} 2001$.

3 Spinello, R., Cyberethics: Morality and Law in Cyberspace, Jones and Bartlett, 2000.

4 Weizenbaum, J., Computer Power and Human Reason - From Judgment to Calculation, W.H. Freeman and Cy, San Francisco, 1976. 
5 Maisl, H., Les problèmes juridiques posés par la déontologie de l'informatique, Study for the Council of Europe (CJ-PD[79]8), Strasbourg, August 6 1979. The following works: Ethics of Data Processing, Categories and Roles in the field of Data Processing (CJ-PD-GT3[81]2 revised), Secretariat Memorandum (CJ$\mathrm{PD}[81] 8)$, and the last report (CJ-PD[82]19) with the minutes of the meeting (CJ-PD[82]31), Strasbourg, 1981-82.

6 Tavani, H., The Tavani Bibliography of Computing, Ethics, and Social Responsibility, http://cyberethics.cbi.msstate.edu/biblio/

7 International Federation for Information Processing, http://www.ifip.or.at/

8 We reported this story in : Berleur, J. and d'Udekem-Gevers, M., Codes of Ethics/Conduct for Computer Societies : The Experience of IFIP, in: GOUJON Ph., Heriard-Dubreuil, B., Eds. Technology and Ethics, A European Quest for Responsible Engineering, European Ethics Network, Peeters, Leuven, 2001.

9 See Berleur, J. \& Brunnstein, Kl. , Eds., Ethics of Computing: Codes, Spaces for Discussion and Law, A Handbook prepared by the IFIP Ethics Task Group, London: Chapman \& Hall, 1996, 336 p., ISBN 0-412-72620-3 (now available from Kluwer Academic Publishers, Boston). See especially the analysis of Berleur, J. and d'Udekem-Gevers, M., pp. 3-41.

10 Habermas, J., De l'éthique de la discussion, Paris, Cerf, 1992. [Orig.: Erlauterungen zur Diskursethik, Engl. Transl.: Justification and Application: Remarks on Discourse Ethics, Cambridge Mass.: The MIT Press, 1993].

" Maesschalck, M., Pour une éthique des convictions. Religion et rationalisation $d u$ monde vécu, Publications des Facultés universitaires Saint-Louis, Coll. Philosophie, Bruxelles, 1994, p.376 From the same author: Normes et contextes. Les fondements d'une pragmatique contextuelle, Georg Olms Verslag, 2001.

12 Council of Europe - Convention on Cybercrime, STE $\mathrm{n}^{\circ} 185$, Opening for signature on 23 November 2001. (http://conventions.coe.int/)

13 Computer Professionals for Social Responsibility, http:/www.cpsr.org/onenet/

14 Cerf, V., The Internet is for Everyone, in : On the Internet, July/August 1999, pp. $8 \mathrm{ff}$.

15 Rinaldi, A. H., The Net: User Guidelines and Netiquette, http://www.fau.edu/netiquette/net/

16 We refer to the consultation launched by the European Commission (DGX) in its 'Green Paper on the Protection of Minors and Human Dignity in Audiovisual and Information Services', COM(96)483, October 16, 1996, and to 'Decision No 276/1999/EC of the European Parliament and of the Council of 25 January 1999 adopting a multiannual Community action plan on promoting safer use of the Internet by combating illegal and harmful content on global networks.' Official Journal of the European Communities, 6.2.1999, L 33/1-11.

17 Berleur, J., Duquenoy, P., and Whitehouse, D., Eds., Ethics and the Governance of the Internet, IFIP-SIG9.2.2, September 1999, IFIP Press, Laxenburg - Austria, ISBN 3-901882-03-0, 56 p. This monograph can be downloaded at the URL http://www.info.fundp.ac.be/ jbl/IFIP/cadresIFIP.html by clicking on 'Ethics and Internet Governance'.

18 Conseil supérieur de l'audiovisuel, World summit of regulators on the Internet and new services: a first review. Paris, November 30-December 1 1999. If the 
concept of co-regulation was promoted during that Summit, Michel Vivant, in the summary of the debates, preferred the term 'multi-regulation' or 'plural regulation'.

19 Berleur, J., Duquenoy, P., and Whitehouse, D., Eds., Ethics and the Governance of the Internet, doc. cit.

BIAC/OECD Forum: Internet Content Self-regulation, http://www1.oecd.org/dsti/sti/it/secur/act/self-reg.htm

21 The net result of this analysis can be found in: Berleur, J., Duquenoy, P., d'Udekem-Gevers, M., Ewbank de Wespin, T., Jones M. et Whitehouse D., Documents d'auto-réglementation - Classification - Un premier inventaire, Namur 2001 (http://www.info.fundp.ac.be/ jbl/IFIP/sig922/selfreg.html).

We would also note with interest: Internet Resources on Self-Regulation and the Internet, The ABCs of Internet Self-Regulation: An Issues Primer.

November 13, 2000. Centre for Law, Commerce and Technology, University of Washington School of Law, http://www.law.washington.edu/lct/publications.html Jacques Berleur and Tanguy Ewbank de Wespin, Self-regulation: Content, Legitimacy and Efficiency - Governance and Ethics, in Human Choice and Computers, Issues of Choice and Quality of Life in the Information Society, Klaus Brunnstein \& Jacques Berleur, Eds., Proceedings of the IFIP-HCC6 Conference, $17^{\text {th }}$ World Computer Congress, Montreal, August 2002, Kluwer Academic Publ., 2002.

Internet Health Care Coalition, eHealth Ethics Intitiative, http://www.ihealthcoalition.org/ethics/ethics.html

US Department of Commerce, Leaders for the New Millenium - Delivering on Digital Progress and Prosperity, The US Government Working Group on Electronic Commerce, 3rd Annual Report, 2000, p. 20.

http://www.ecommerce.gov/ecomnews/ecommerce2000annual.pdf

International Chamber of Commerce, ICC Guidelines on Advertising and Marketing on the Internet, 2 April 1998,

http://www.iccwbo.org/home/statements_rules/rules/1998/internet guidelines.a $\mathrm{sp}$

26 Charte d'édition électronique, (Le Monde, La Tribune, L'Agefi, Les Echos, Investir, ZDNet), http://www.liberation.com/licence/charte.html

27 Conseil supérieur de l'audiovisuel, World summit of regulators on the Internet and new services: a first review. Paris, November 30-December 1 1999. The summary of foreign contributions in view of the Summit appeared in La Lettre $d u$ CSA, No. 121, October 1999. Also see La Lettre $d u$ CSA, No. 129, June 2000 , on the activities of the CSA in 1999 and the summary of M. Vivant formerly available at http://www.csa.fr/csaflash.htm (and today ad instar manuscr.). This summit was placed under the aegis of UNESCO: several echoes are to be found at http://www.unesco.org/webworld/news/csa_summit.shtml Forum des Droits sur l'Internet, http://www.foruminternet.org/

29 Electronic Commerce Platform Nederland (ECP-NL), Model Code of Conduct for Electronic Business, Draft 4.0, October 2001, http://www.ecp.nl/ENGLISH/publication/cocdraft4.0ENG.pdf 
30 Falque-Pierrotin, Is., Quelle régulation pour Internet et les réseaux ? in : Le Monde, November 1999, p. 17.

31 Global Business Dialogue on Electronic Commerce (GBDe), http://www.gbde.org

32 Waltermann, J. and Machill, M., Eds., Protecting our Children on the Internet, Towards a New Culture of Responsibility, Bertelsmann Foundation Publishers, Gütersloh, 2000. See in particular the chapter 1 'Memorandum on Selfregulation of Internet Content', p. 25-57 and, in that chapter, §3 'Selfregulation as a Foundation', p. 35-40.

33 The full sequence of the documents and actions that can be considered as a follow up of the Green paper on the protection of minors and human dignity is given at: http://europa.eu.int/comm/avpolicy/regul/new_srv/pmhd_en.htm

34 Bertelsmann Foundation, Toward a Model Code of $\bar{C}$ onduct on the Internet, prepared by Price, M,. E. and Verhulst, St. G., Hanover, June 30, 2000, http://www.bertelsmann-stiftung.de/internetcontent/english/content/c4000.htm Internet Content Rating Association (ICRA): http://icra.org International Chamber of Commerce, GUIDEC II, General Usage for International Digitally Ensured Commerce (version II), October 2001 http://www.iccwbo.org/home/guidec/guidec two/contents.asp eConfidence forum, A European Commission initiative promoting information exchange and discussions about eConfidence, http://econfidence.jrc.it See : Principles for eCommerce codes of conduct.

38 Berleur, J., Self-Regulation and Democracy: Choice and Limits?, in: User Identification \& Privacy Protection, Applications in Public Administration \& Electronic Commerce, Fischer-Hübner, S., Quirchmayr, G. S., \& Yngström, L., Eds., Dept of Computer and Systems Sciences, Stockholm University/Royal Institute of Technology, Report Series 99-007, 1999, ISBN 91-7153-909-3, p. $1-19$.

39 There are several formulations of the Kantian categorical imperative, one of them being: "We must be able to will that a maxim of our action should become a universal law - this is the general canon for all moral judgement of action." See: Immanuel Kant, Groundwork of the Metaphysic of Morals, translated and analysed by H. J. Paton, New York: Harper \& Row, 1964, p. 91.

40 We would read with interest the dossier ' $L$ a ruée des entreprises vers l'éthique', which appeared in Le Monde Initiatives, December 2001. 